\title{
Yanıt Yüzey Metodolojisi Kullanılarak Dulavratotu (Arctium Lappa) 'dan Antioksidanların Mikrodalga Destekli Ekstraksiyonunun Modellenmesi ve Optimizasyonu
}

\author{
Burcu Bekdeşer ${ }^{1 *}$ \\ 1 İstanbul Üniversitesi-Cerrahpaşa, Mühendislik Fakültesi, Kimya Bölümü, İstanbul, Türkiye (ORCID: 0000-0003-4555-2434)
}

(İlk Geliş Tarihi 8 Ekim 2019 ve Kabul Tarihi 6 Kasım 2019)

(DOI: 10.31590/ejosat.631016)

\begin{abstract}
ATIF/REFERENCE: Bekdeşer B. (2019). Yanıt Yüzey Metodolojisi Kullanılarak Dulavratotu (Arctium Lappa) 'dan Antioksidanların Mikrodalga Destekli Ekstraksiyonunun Modellenmesi ve Optimizasyonu. Avrupa Bilim ve Teknoloji Dergisi, (17), 655-662.

$\ddot{O} \mathbf{z}$

Dulavratotu (Arctium lappa L.), geleneksel tıpta sıklkkla kullanılan ticari olarak önemli bir bitkidir. Mikrodalga destekli ekstraksiyonun (MAE) sicaklık, ekstraksiyon süresi, katı / solvent oranı ve solvent konsantrasyonunu içeren optimum çalışma koşulları, cevap yüzey metodolojisi (RSM) kullanılarak belirlendi. Dulavratotu yaprağı ekstraktlarının toplam antioksidan kapasitesi ve toplam fenolik içeriği sırasıyla CUPRAC ve Folin yöntemleri ile incelenmiştir. İkinci dereceden bir polinom modelinin TAC ve TPC verimini tanımlayan en iyi model olduğu bulundu ve iki yanıt için hesaplanan tüm modeller anlamlı bulundu $(p<0.0001)$. TAC ve TPC değerlerinin sırasıyla $0.046-0.185 \mathrm{mmol}$ TR / g DS, $0.303-0.722 \mathrm{mmol} \mathrm{TR} / \mathrm{g}$ DS arasında değiştiği görülmüştür. En yüksek TAC ve TPC değerleri, $\mathrm{X}_{1}=90{ }^{\circ} \mathrm{C}, \mathrm{X}_{2}=6$ dak, $\mathrm{X}_{3}=\% 21.7 \mathrm{ve}, \mathrm{X}_{4}=0.21 \mathrm{~g} / 20 \mathrm{~mL}$ deney koşulları altında elde edildi. Ekstraksiyon sıcaklığının, MAE'nin tüm operasyonel parametreleri arasında en önemli işletim faktörü olduğu bulundu. Optimum ekstraksiyon koşullarında, deneysel olarak elde edilen maksimum TAC ve TPC veriminin öngörülen değerlerine çok yakın olduğu bulundu, böylece kullanılan modelin uygunluğu ve RSM'nin ekstraksiyon koşullarını optimize etmedeki başarısı görülmektedir. Bu çalışmada optimize edilmiş MAE metodu, dulavratotundan antioksidanlarını etkin ve ekonomik bir şekilde ekstraksiyonu için gıda ve ilaç endüstrisinde uygulanabilir.
\end{abstract}

\section{Modelling and Optimizing Microwave-Assisted Extraction of Antioxidants From Burdock (Arctium Lappa) Using Responce Surface Methodology}

\begin{abstract}
Burdock (Arctium lappa L.) is a commercially an important plant often used in traditional medicine. The optimum operating conditions of microwave-assisted extraction (MAE) including temperature $\left(\mathrm{X}_{1}\right)$, extraction time $\left(\mathrm{X}_{2}\right)$, solvent concentration $\left(\mathrm{X}_{3}\right)$ and solid to solvent ratio $\left(\mathrm{X}_{4}\right)$ were ascertained by employing response surface methodology (RSM). The total antioxidant capacity and total phenolic content of burdock leaves extracts were investigated by CUPRAC and Folin assays respectively. A second-order polynomial model was found to be the best model that describes TAC and TPC of yield, and all models calculated for the two responses were found significant $(\mathrm{p}<0.0001)$. It was observed that the values of TAC and TPC varied between $0.046-0.185 \mathrm{mmol}$ TR / g DS, $0.303-0.722 \mathrm{mmol}$ TR / g DS, respectively. The highest TAC and TPC values was obtained under the experimental conditions
\end{abstract}

* Sorumlu Yazar: İstanbul Üniversitesi, Mühendislik Fakültesi, Kimya Bölümü, İstanbul, Türkiye, ORCID: 0000-0003-4555-2434, burcubek@istanbul.edu.tr 
of $\mathrm{X}_{1}=90^{\circ} \mathrm{C}, \mathrm{X}_{2}=6 \mathrm{~min}, \mathrm{X}_{3}=21.7 \%$ and, $\mathrm{X}_{4}=0.21 \mathrm{~g} / 20 \mathrm{~mL}$. The extraction temperature was found to be the most significant operating factor amongst all operational parameters of MAE. At optimum extraction conditions, the maximum yield of TAC and TPC obtained experimentally were found to be very close to their predicted values as a result the suitability of the model used, and the success of RSM in optimizing the extraction conditions were demonstrated. MAE method optimized in this study can be applied for effectively and economically extract antioxidants from burdock in food and pharmaceutical industries.

Keywords: Microwave-assisted extraction, antioxidants, burdock, response surface methodology.

\section{Introduction}

Burdock (Arctium lappa) is an edible plant from a member of the Asteraceace family. Burdock commonly used as a traditional medicinal plant because of its beneficial effects related to inflammatory disorders such as arteriosclerosis, gout, hepatitis. Burdock has anti - inflammatory, anti-mutagenic, anti-aging properties due to its rich antioxidant content (Chen et al 2004). Ionescu et al (2013) investigated the antimicrobial activity of some hydroalcoholic extracts of burdock and reported its antimicrobial activity against the bacterial strains of Escherichia coli and Salmonella. Ferracane et al (2010) analyzed the bioactive metabolic profile of burdock seeds, leaves and roots by liquid chromatography coupled to elecrospray tandem mass spectrometry. Caffeic acid, arctiin, chlorogenic acid, cynarin, luteolin and quercitrin were found in burdock extracted through sonication at room temperature for 30 min. In another study, Lou et al (2010) performed UPLC- MS/MS analysis of burdock leaves and detect ten different active compounds such as luteolin, caffeic acid, rutin, benzoic acid, quercetin, quercitrin, chlorogenic acid, cynarin, p-coumaric and arctiin. In literature, several studies have been investigated the total phenolic content and free radical scavenging activity of different parts of burdock (roots, leaves and seeds) by using varied extraction techniques. Rodriguez et al (2018) determined composition and antioxidant activity of burdock root extracts by using classical extraction and supercritical fluid extraction. Jimenez-Zamora et al (2016) determined the antioxidant capacity and total phenolic content of 36 plants including burdock consumed in Spain as infusion. Lin et al (1996) determined the hydroxyl and superoxide radical scavenging activity of burdock extract by using an electron spin resonance spectrometer. Milani et al (2011) optimized conventional and ultrasound-assisted extraction of inulin from burdock root using responce surface methodology.

RSM is a statistical analysis of data for evaluate multiple parameters and their interactions. Thus, the optimization of processing parameters can be easily achieved, keeping the number of experiments to a minumum (Sun et al 2014). As far as is known, optimization of microwave - assisted extraction of antioxidant compounds from burdock using RSM has not been studied in the literature.

In this study, preparation of burdock leaves extracts for analysis was performed using MAE, which has distinct advantages over conventional extraction methods. MAE reduced extraction time and solvent volume as compared to conventional extraction method. The reproducibility and recovery parameters are better compared to the classical extraction method. Moreover, this method is highly suitable for the extraction of small molecule phenolic compounds such as phenolic acids, quercetin, isoflavin and resveratrol since these molecules are stable at microwave heating conditions up to $100^{\circ} \mathrm{C}$ for 20 minutes (Azwanida 2015). The maximum extraction yield was obtained by optimization of operational parameters affecting extraction efficiency such as time and temperature using RSM.

\section{Materials and Methods}

\subsection{Reagent and Chemicals}

Chemical substances including neocuproine, methanol, ethanol, and Folin - Ciocalteu reagent copper (II) chloride, ammonium acetate, sodium potassium tartarate $\left(\mathrm{NaKC}_{4} \mathrm{H}_{4} \mathrm{O}_{6}\right)$, copper (II) sulfate, sodium hydroxide and sodium carbonate were of analytical reagent grade, and obtained from the Merck (Darmstadt, Germany). Burdock (arctium lappa) was purchased from a commercial herb seller (Arifoğlu, Istanbul, Turkey). The burdock leaves was milled into uniform dry powder by grinder and stored at $4{ }^{\circ} \mathrm{C}$.

\subsection{Instrumentation}

ETHOS - One (Milestone) extraction system was used to extraction of burdock leaves. UV - visible spectra and absorption measurements were achieved by using Varian CARY 100 UV - Vis spectrophotometer. The MAE of antioxidants from burdock leaves was modelled and optimized by using Design-Expert ${ }^{\circ}$ Software Version 11 Trial.

\subsection{Microwave - Assisted Extraction of Burdock}

Thirty experimental MAE runs were carried out on different temperatures $\left(50-100{ }^{\circ} \mathrm{C}\right)$, solvent concentration (ethanol \% in water), extraction time $(1-10 \mathrm{~min})$ and solid to solvent ratio $(\mathrm{g} / 20 \mathrm{~mL})$. In each experimental run, varying quantities sample $(0.1-0.4 \mathrm{~g})$ was mixed with varying quantities $20 \mathrm{~mL}$ aqueous ethanol solution $(0 \%, 50 \%, 100 \%(\mathrm{v} / \mathrm{v}))$ in an inner vessel. The microwave power $(500-1500 \mathrm{~W})$ was automatically controlled by a system in the oven according to temperature in of the oven. Extraction of antioxidants from burdock leaves under optimal experimental conditions was performed with using MAE system as follows: $0.21 \mathrm{~g}$ of burdock leaves in $20 \mathrm{~mL}$ of $21.7 \%$ aqueous ethanol solutions were added to the Teflon vessel. Burdock leaves sample in solvent was irradiated with microwaves $3 \mathrm{~min}$ for heating to the $90^{\circ} \mathrm{C}$ and, kept there for $6.0 \mathrm{~min}$, and $5 \mathrm{~min}$ for cooling. The extracts cooled to room temperature were filtered through 0.45 micron membrane filters. The extracts preserved in a refrigerator until use. Three replicate extractions were obtained from the burdock leaves and spectrophotometric measurements of each extract were repeated three times. 


\subsection{Determination of Total Phenolic Content (TPC)}

Folin-Ciocalteau assay was applied to determine TPC values of the burdock leaves extract (Singleton et al 1999). The reagents which were used in Folin - Ciocalteau assay were as follow: Lowry $\mathrm{C}$ reagent was freshly prepared as mixture of $50 \mathrm{~mL}$ Lowry A solution $\left(2 \% \mathrm{Na}_{2} \mathrm{CO}_{3}\right.$ in $\left.0.1 \mathrm{M} \mathrm{NaOH}\right)$ and $1 \mathrm{~mL}$ Lowry B solution $\left(0.5 \% \mathrm{CuSO}_{4}\right.$ in $\left.1 \% \mathrm{NaKC}_{4} \mathrm{H}_{4} \mathrm{O}_{6}\right)$. $2.5 \mathrm{~mL}$ of Lowry $\mathrm{C}$ solution, $x \mu \mathrm{L}$ of the burdock leaves extract, and $(1-x) \mathrm{mL} \mathrm{H}_{2} \mathrm{O}$ were added in a test tube and allowed to stand at room temperature for ten minutes. Finally $0.25 \mathrm{~mL}$ of Folin reagent was added, and absorbance was measured at $750 \mathrm{~nm}$ after $30 \mathrm{~min}$.

\subsection{Determination of Total Antioxidant Capacity (TAC)}

CUPRAC assay was applied to determine TAC values of the burdock leaves (Apak et al 2004). $1 \mathrm{~mL} \mathrm{each} \mathrm{of} \mathrm{CuCl}_{2}(10 \mathrm{mM}$ ), neocuproine $(7.5 \mathrm{mM}), \mathrm{pH}=7$ ammonium acetate solution $(1 \mathrm{M})$ and $x \mathrm{~mL}$ of the burdock leaves extract were added to test tube in this order. A cupric neocuproine complex (Cu (II) - Nc) was reduced to the cuprous chelate in the presence of burdock leaves extract. After $30 \mathrm{~min}$. absorbance of the cuprous chelate was recorded at $450 \mathrm{~nm}$.

\subsection{Experimental Design}

Optimizing microwave-assiated extraction of antioxidants from burdock was achieve by using a face - centered composite design (FCCD) which was applied to the independent parameters. According to equation 1 ; $\mathrm{Y}$ is the dependent variables (response), $\beta_{0}$ is an intercept term, $\mathrm{k}$ is the factor number, $\mathrm{X}$ is the independent variable and $\varepsilon$ is experimental error.

$$
Y=\beta_{0}+\sum_{i=1}^{k} \beta_{i} x_{i}+\sum_{i=1}^{k} \beta_{i i} x_{i}^{2}+\sum_{i=1}^{k-1} \sum_{j=2}^{k} \beta_{i j} x_{i} x_{j}+\varepsilon \quad \text { Eq. (1) }
$$

In this study, the dependent variables (Y) identify as TPC and TAC, the factor number is $4(\mathrm{k})$ and independent variables $(\mathrm{X})$ identify as $\mathrm{X}_{1}$ : temperature, $\mathrm{X}_{2}$ : time $\mathrm{X}_{3}$ : ethanol concentration, $\mathrm{X}_{4}$ : solid to solvent ratio. The experimental data indicated that the most suitable model was determined as second order polynomial model for define the values of TPC and TAC as a function of independent variables. The relation between the independent variables and response using Design-Expert program was identified by analysis of ANOVA test.

\section{Results and Discussion}

According to the proposed design, thirty experiments were performed and the experimental values TAC and TPC obtained are shown in Table 1. It was observed that the values of TAC and TPC varied between $0.046-0.185 \mathrm{mmol}$ TR / g DS, $0.303-0.722$ mmol TR / g DS, respectively. 
Table 1. FCCD Layout and Experimental Data

\begin{tabular}{|c|c|c|c|c|c|c|}
\hline \multirow[b]{2}{*}{$\begin{array}{c}\text { Run } \\
\text { No }\end{array}$} & \multicolumn{4}{|c|}{ Factors } & \multicolumn{2}{|c|}{ Response } \\
\hline & $\begin{array}{c}\text { Temperature } \\
\left({ }^{\circ} \mathrm{C}\right)\end{array}$ & $\begin{array}{l}\text { Time } \\
(\min )\end{array}$ & $\begin{array}{c}\text { Ethanol } \\
\text { concentration } \\
(\%, \mathbf{v} / \mathbf{v})\end{array}$ & $\begin{array}{c}\text { Solid to } \\
\text { solvent ratio } \\
\text { (g/20 } \mathrm{mL})\end{array}$ & $\begin{array}{c}\text { TAC } \\
(\mathrm{mmol} \text { TR / g DS) }\end{array}$ & $\begin{array}{c}\text { TPC } \\
(\mathrm{mmol} \text { TR / g DS) }\end{array}$ \\
\hline 1 & 75 & 4 & 50 & 0.25 & 0.154 & 0.702 \\
\hline 2 & 75 & 4 & 50 & 0.40 & 0.165 & 0.718 \\
\hline 3 & 75 & 4 & 50 & 0.25 & 0.149 & 0.675 \\
\hline 4 & 75 & 4 & 20 & 0.25 & 0.197 & 0.738 \\
\hline 5 & 75 & 4 & 50 & 0.25 & 0.145 & 0.694 \\
\hline 6 & 50 & 7 & 20 & 0.1 & 0.095 & 0.482 \\
\hline 7 & 100 & 7 & 20 & 0.1 & 0.185 & 0.722 \\
\hline 8 & 100 & 7 & 20 & 0.4 & 0.178 & 0.723 \\
\hline 9 & 50 & 1 & 20 & 0.1 & 0.084 & 0.45 \\
\hline 10 & 75 & 1 & 50 & 0.25 & 0.165 & 0.722 \\
\hline 11 & 100 & 1 & 20 & 0.4 & 0.171 & 0.712 \\
\hline 12 & 50 & 7 & 20 & 0.4 & 0.075 & 0.411 \\
\hline 13 & 50 & 1 & 20 & 0.4 & 0.069 & 0.396 \\
\hline 14 & 50 & 7 & 80 & 0.1 & 0.065 & 0.391 \\
\hline 15 & 75 & 4 & 50 & 0.25 & 0.152 & 0.699 \\
\hline 16 & 50 & 1 & 80 & 0.4 & 0.046 & 0.303 \\
\hline 17 & 50 & 4 & 50 & 0.25 & 0.093 & 0.488 \\
\hline 18 & 100 & 7 & 80 & 0.1 & 0.162 & 0.708 \\
\hline 19 & 75 & 4 & 80 & 0.25 & 0.135 & 0.687 \\
\hline 20 & 75 & 7 & 50 & 0.25 & 0.181 & 0.719 \\
\hline 21 & 50 & 7 & 80 & 0.4 & 0.047 & 0.328 \\
\hline 22 & 100 & 1 & 80 & 0.1 & 0.154 & 0.708 \\
\hline 23 & 100 & 1 & 80 & 0.4 & 0.143 & 0.701 \\
\hline 24 & 100 & 4 & 50 & 0.25 & 0.167 & 0.717 \\
\hline 25 & 75 & 4 & 50 & 0.25 & 0.147 & 0.708 \\
\hline 26 & 50 & 1 & 80 & 0.1 & 0.055 & 0.358 \\
\hline 27 & 75 & 4 & 50 & 0.25 & 0.159 & 0.713 \\
\hline 28 & 100 & 7 & 80 & 0.4 & 0.148 & 0.704 \\
\hline 29 & 75 & 4 & 50 & 0.1 & 0.145 & 0.709 \\
\hline 30 & 100 & 1 & 20 & 0.1 & 0.171 & 0.716 \\
\hline
\end{tabular}

To predict the yield of TAC and TPC a second - order polynomial model was generated by using a multiple nonlinear regression analysis of the experimental data. The adapted quadratic models for TAC and TPC are given in Eqs. (2) - (3), respectively.

$\mathrm{TAC}=-0.300759+0.010473 \mathrm{X}_{1}-0.003319 \mathrm{X}_{2}-0.000437 \mathrm{X}_{3}+0.212680 \mathrm{X}_{4}+0.000005 \mathrm{X}_{1} \mathrm{X}_{2}+0.000001 \mathrm{X}_{1} \mathrm{X}_{3}+0.000500 \mathrm{X}_{1} \mathrm{X}_{4}-$ $0.00000972 \mathrm{X}_{2} \mathrm{X}_{3}-0.00333 \mathrm{X}_{2} \mathrm{X}_{4}-0.000139 \mathrm{X}_{3} \mathrm{X}_{4}-0.000059 \mathrm{X}_{1}^{2}+0.000713 \mathrm{X}_{2}^{2}-0.00000064 \mathrm{X}_{3}^{2}-0.514620 \mathrm{X}_{4}^{2}$

$\mathrm{TPC}=-0.769553+0.034239 \mathrm{X}_{1}+0.014332 \mathrm{X}_{2}-0.001115 \mathrm{X}_{3}-0.060750 \mathrm{X}_{4}-0.000071 \mathrm{X}_{1} \mathrm{X}_{2}+0.000026 \mathrm{X}_{1} \mathrm{X}_{3}+0.003817 \mathrm{X}_{1} \mathrm{X}_{4}-$ $0.00000208 \mathrm{X}_{2} \mathrm{X}_{3}-0.002361 \mathrm{X}_{2} \mathrm{X}_{4}-0.000014 \mathrm{X}_{3} \mathrm{X}_{4}-0.000200 \mathrm{X}_{1}^{2}-0.000758 \mathrm{X}_{2}^{2}-0.000016 \mathrm{X}_{3}^{2}-0.614425 \mathrm{X}_{4}^{2}$

The temperature was found to be the most significant operating factor on the extraction efficiency amongst the other factors due to its the highest F-value (751.65) and the smaller p-value $(<0.0001)$. Table 2 shows results of the analysis of variance (ANOVA) which demonstrated the significance and adequacy of developed quadratic models for TAC and TPC. All of the models were found meaningful and adequate to show the correlation between the response and parameters with low p-value $(<0.0001$ for TAC and TPC) from the ANOVA. The determination coefficient $\left(\mathrm{R}^{2}\right)$ showing the model's compatibility with the experimental data and the adjusted determination coefficient (Adj. $\mathrm{R}^{2}$ ) were compatible with each other (the difference is less than 0.2 ). The predicted $\mathrm{R}^{2}$ of 0.8569 and 0.9515 reasonably agree with the adjusted $\mathrm{R}^{2}$ of 0.9244 and 0.9735 for TAC and TPC, respectively. The adequate precision which evaluate the signal to noise ratio and is desired to be greater than 4 were found to be 16.032 and 25.278 for TAC and TPC, respectively. 
Table 2. ANOVA for the Effect of Independent Variables on the Yield of TAC and TPC Using a Quadratic Response Surface Model

\begin{tabular}{|c|c|c|c|c|c|c|}
\hline \multirow{2}{*}{ Source } & \multicolumn{3}{|c|}{ TPC } & \multicolumn{3}{c|}{ TAC } \\
\cline { 2 - 7 } & Model & $\begin{array}{c}\text { Lack of } \\
\text { fit }\end{array}$ & $\begin{array}{c}\text { Pure } \\
\text { error }\end{array}$ & Model & $\begin{array}{c}\text { Lack of } \\
\text { fit }\end{array}$ & $\begin{array}{c}\text { Pure } \\
\text { error }\end{array}$ \\
\hline Degree of freedom & 14 & 10 & 5 & 14 & 10 & 5 \\
\hline Sum of squares & 0.6282 & 0.0078 & 0.0009 & 0.0573 & 0.0022 & 0.0001 \\
\hline Mean square & 0.0449 & 0.0008 & 0.0002 & 0.0041 & 0.0002 & 0.0003 \\
\hline$F$ value & 77.22 & 4.42 & & 26.33 & 8.47 & \\
\hline$P$ value & $<0.0001$ & 0.0573 & & $<0.0001$ & 0.0147 & \\
\hline
\end{tabular}

The 3D response surface plots as a function of temperature shown in Figures $1-3$ demonstrate the effect of parameters on TAC and TPC values. In the literature, the antioxidant activity of burdock extracts were determined by using different solvents such as water, ethanol, methanol, chloroform and n-hexane (Duh 1998). Among the solvents used for extraction, water showed the strongest antioxidant activity compared to extracts prepared with other solvents. In this study the ethanol - water binary solvent mixture preferred as an extraction solvent for the extraction process due to its health compatibility, environmentally suitability and low cost.

The usage of aqueous mixtures of alcohols as solvents for the extraction of antioxidants is also known to be more effective than the corresponding single component solvent system and improves the extraction rate (Spingo et al 2007, Alonso et al 1991). Simic et al. (2016) emphasized that ethanol-water binary solvent mixture is widely used for pharmaceutical and food production due to its low toxicity, environmentally suitability, high extraction yield and health compatibility. Also as shown in Figure 1, the yields of TAC and TPC increased when ethanol percentage in water decreased up to a certain value. $21.17 \%$ ethanol concentration showed the greatest efficiency in the extraction of antioxidants from efficiency burdock leaves.

Among the studied extraction parameters, time and solid to solvent ratio had the lowest impact on the yields of TAC and TPC. Figure 2 shows that there was no significant change on the yield of TAC and TPC with increasing solid to solvent ratio. The yields of TAC and TPC increased slightly with solid to solvent ratio up to $0.21 \mathrm{~g} / 20 \mathrm{~mL}$ solvent. The decrease in the extraction yield after a certain solid to solvent ratio is proper with the basis of mass transfer because when a lower solid to solvent ratio is used, the pushing force is expected to be higher (Illbay et al 2014).

In general, prolonged extraction times increase the extraction efficiency of bioactive compounds because of time required for the solvent to penetrate the solid sample, dissolve the soluble components in the sample, and release the solvent from the sample with the dissolved components (Gan and Latiff 2011, Lee et al 2006, Fan et al 2008). However, long extraction times are not economically feasible and need to be optimized. In this study, it was observed that there was no significant change in the efficiency of TAC and TPC with increasing extraction time (Figure 3) and the extraction time of 6 minutes was sufficient for maximum extraction efficiency. The extraction time of 6 minutes was sufficient for getting the maximum yield of TAC and TPC.

The most important parameters that need to be optimized to reduce the energy cost of the extraction process are temperature and time (Spingo et al 2007). The continuous increase in TAC and TPC values of the extracts as a function of temperature can be seen from Figures 1-3. This can be clarified by the enhancing the solubility of solute and the diffusion coefficient with increase of temperature as mentioned in many studies (Shi et al 2003), In this study, it was observed that the highest efficiency for the extraction of antioxidants from burdock leaves in the range of $80-90{ }^{\circ} \mathrm{C}$. In order to prevent structural degradation of phenolics, optimization studies were performed at maximum 100 degrees Celsius (Spingo et al 2007, Dent et al 2013, Naczk et al 2004). 


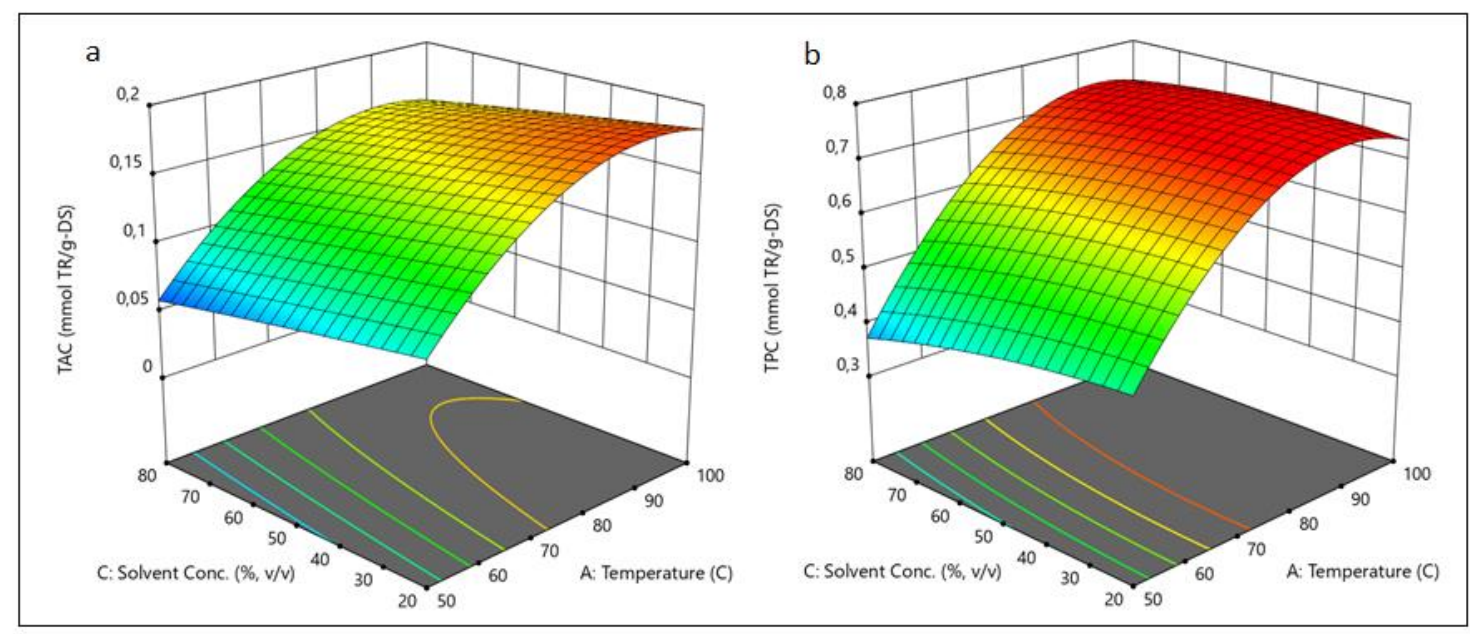

Figure 1. The 3D Surface Plot for the (a) TAC and (b) TPC of the Burdock Leaves Extract As A Function of Temperature To Solvent Concentration (Solid to solvent ratio $=0.25 \mathrm{~g} / 20 \mathrm{~mL}$ and extraction time $=4 \mathrm{~min}$ )

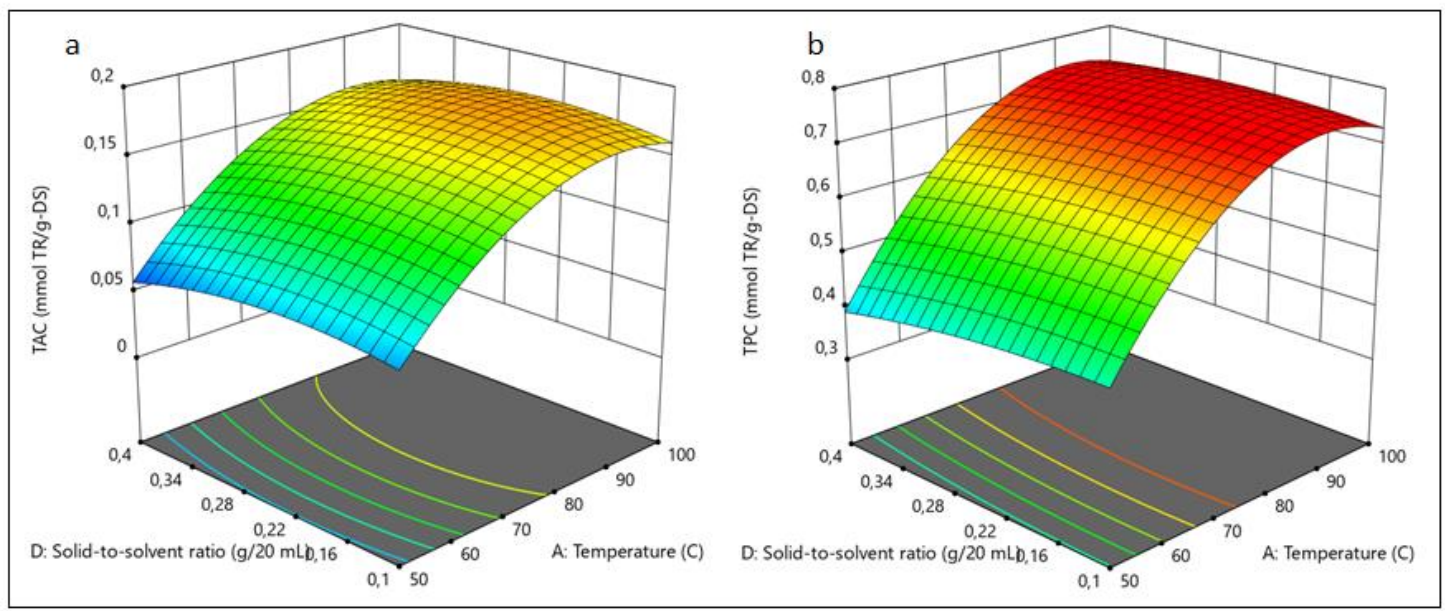

Figure 2. The 3D Surface Plot for the (a) TAC and (b) TPC of the Burdock Leaves Extract As A Function Of Temperature To Solid To Solvent Ratio (Solvent concentration $=50 \%$ and extraction time $=4 \mathrm{~min}$ )

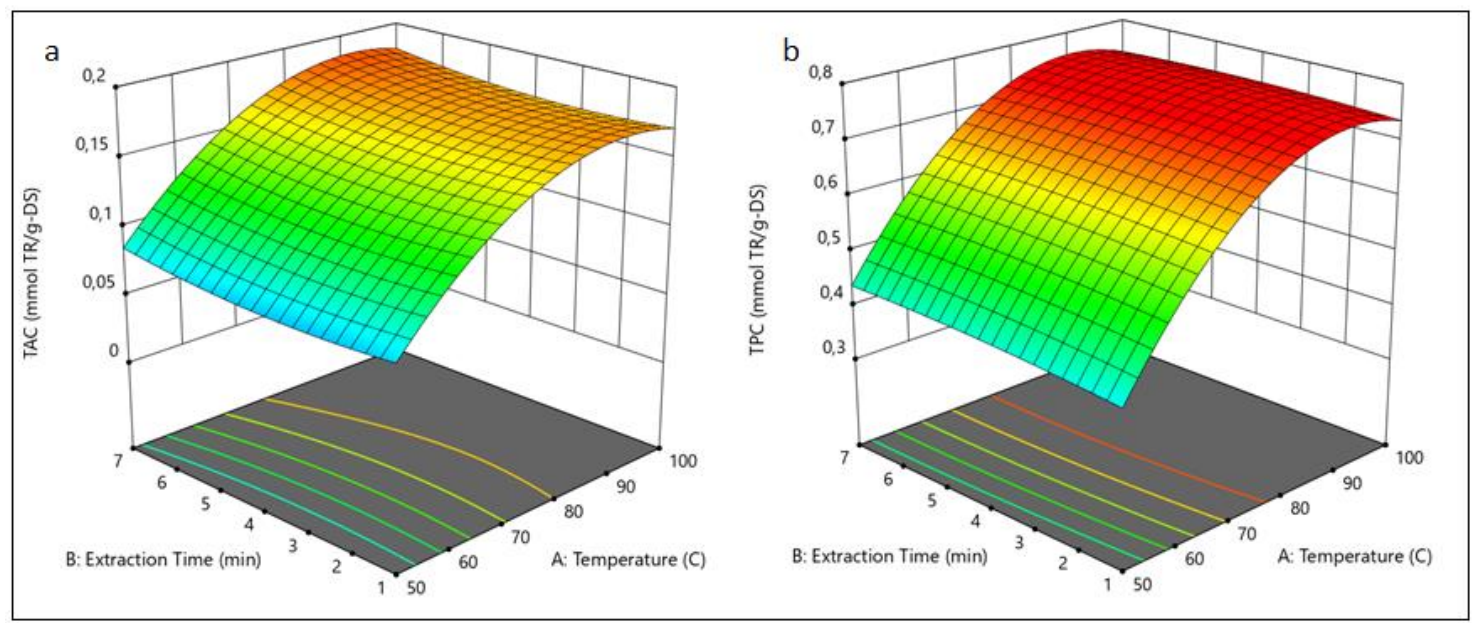

Figure 3. The 3D Surface Plot for the (a) TAC and (b) TPC of the Burdock Leaves Extract As A Function of Temperature to Extraction time (Solvent concentration $=50 \%$ and solid to solvent ratio $=0.25 \mathrm{~g} / 20 \mathrm{~mL}$ )

The optimum MAE conditions for the highest yields of TAC $(0.197 \mathrm{mmol}$ TR / g - DS) and TPC (0.722 mmol TR / g - DS) were obtained as follows: $21 \%$ ethanol aqueous solution $(\mathrm{v} / \mathrm{v}), 90^{\circ} \mathrm{C}, 6.0 \mathrm{~min}$, and $0.21 \mathrm{~g} / 20 \mathrm{~mL}$. The predicted values are compatible with experimental values obtained at optimum extraction conditions. The predicted values for TAC and TPC were calculated as 0.194 
mmol TR / g - DS and $0.75 \mathrm{mmol}$ TR / g - DS, respectively. As a result, the design model was considered to be reliable and accurate for determining TAC and TPC of burdock leaves extracts obtained using microwave assisted extraction.

\section{Conclusion}

Modelling and optimizing microwave-assisted extraction of antioxidants from burdock (arctium lappa) using responce surface methodology is the first time in the literature. Response surface methodology was successfully used for the design of experiments, modeling and optimization of the extraction of antioxidant compounds which is the most important step in the determination of the antioxidant capacity of burdock. The optimum extraction conditions for getting the maximum yield of TAC and TPC were determined. The extraction temperature was found to be the most significant operating factor on the MAE of antioxidants from burdock.

These experimental conditions allow a fast, quantitative and maximum extraction of antioxidants from burdock. MAE method optimized in this study can be an important alternative method which can be applied for effectively and economically extract antioxidants from burdock in food and pharmaceutical industries in the future.

\section{Acknowledgments}

The author expresses their gratitude to Istanbul University-Cerrahpasa Food Antioxidants Measurement Application \& Research Center (Gida Antioksidanlari Olcumu Uygulama ve Arastirma Merkezi) for providing its research infrastructures.

\section{References}

Alonso E., Bourzeix M., Revilla E. (1991) Suitability of water/ ethanol mixtures for the extraction of catechins and proanthocyanidins from Vitis vinifera seeds contained in a winery by-product. Seed Science and Technology,19, 542-552.

Apak R., Güçlü K., Özyürek M., Karademir S. E. (2004) Novel total antioxidant capacity index for dietary polyphenols and vitamins $\mathrm{C}$ and $\mathrm{E}$, using their cupric ion reducing capability in the presence of neocuproine: CUPRAC method. Journal of Agricultural and Food Chemistry, 52, 7970-7981. doi:10.1021/jf048741x

Azwanida N. N. (2015) A Review on the extraction methods use in medicinal plants, principle, strength and limitation. Medicinal \&Aromatic Plants, 4, 196-202. doi:10.4172/2167-0412.1000196

Chen F., Wu A., Chen C. (2004) The influence of different treatments on the free radical scavenging activity of burdock and variations of its active components, Food Chemistry, 86, 479-484. doi: 10.1016/j.foodchem.2003.09.020

Dent M., Dragović-Uzelac V., Penić M., Brnčić M., Bosiljkov T., Levaj B. (2013) The effect of extraction solvents, temperature and time on the composition and mass fraction of polyphenols in dalmatian wild sage (Salvia officinalis L.) extracts. Food Technology and Biotechnology, 51, 84-91.

Duh P. (1998) Antioxidant activity of Burdock (Arctium lappa Linne): Its scavenging effect on free-radical and active oxygen. Journal of the American Oil Chemists' Society, 75, 455-461.

Fan G., Han Y., Gu Z., Chen D. (2008) Optimizing conditions for anthocyanins extraction from purple sweet potato using response surface methodology (RSM). LWT-Food Science and Technology, 41, 155-160. doi: 10.1016/j.1wt.2007.01.019

Ferracane R., Graziani G., Gallo M., Fogliano V., Ritieni A. (2010) Metabolic profile of the bioactive compounds of burdock (Arctium lappa) seeds, roots and leaves. Journal of Pharmaceutical and Biomedical Analysis, 51, 399-404. doi: 10.1016/j.jpba.2009.03.018

Gan C. Y., Latiff A. A. (2011) Optimisation of the solvent extraction of bioactive compounds from Parkia speciosa pod using response surface methodology. Food Chemistry, 124, 1277-1283. doi: 10.1016/j.foodchem.2010.07.074

Ionescu D., Predan G., Rızea G. D., Mihele D., Dune A., Ivopol G., Ionıţă C. (2013) Antimicrobial activity of some hydroalcoholıc extracts of artichoke (Cynara Scolymus), burdock (Arctium Lappa) and dandelion (Taraxacum Officinale). Bulletin of the Transilvania University of Braşov, 6, 114-120.

İlbay Z., Şahin S., Büyükkabasakal K. (2014) A novel approach for olive leaf extraction through ultrasound technology: Response surface methodology versus artificial neural networks. Korean Journal of Chemical Engineering, 31, 1661-1667. doi: 10.1007/s11814-014-0106-3

Jiménez-Zamora A., Delgado-Andrade C., Rufián-Henares J. A. (2016) Antioxidant capacity, total phenols and color profile during the storage of selected plants used for infusion. Food Chemistry, 199, 339-346. doi: 10.1016/j.foodchem.2015.12.019

Lee W., Yusof S., Hamid N., Baharin B. (2006) Optimizing conditions for hot water extraction of banana juice using response surface methodology (RSM). Journal of Food Engineering, 75, 473-479. doi: 10.1016/j.jfoodeng.2005.04.062

Lin C., Lin J., Yang J., Chuang S., Ujiie T. (1996) Anti-inflammatory and radical scavenge effects of Arctium lappa. The American Journal of Chinese Medicine, 24,127-137. doi: 10.1142/S0192415X96000177 
Lou Z., Wang H., Zhu S., Zhang M., Gao Y., Ma C., Wang Z. (2010) Improved extraction and identification by ultra performance liquid chromatography tandem mass spectrometry of phenolic compounds in burdock leaves. Journal of Chromatography A,1217, 2441-2446. doi:10.1016/j.chroma.2009.12.022

Milani E., Koocheki A., Golimovahhed Q. A. (2011) Extraction of inulin from Burdock root (Arctium lappa) using high intensity ultrasound, International Journal of Food Science and Technology, 46, 1699-1704. doi: 10.1111/j.1365-2621.2011.02673.x

Naczk M., Shahidi F. (2004) Extraction and analysis of phenolics in food. Journal of Chromatography A, 1054, 95-111. doi: 10.1016/j.chroma.2004.08.059

Rodriguez J. M. F., Custódio de Souza A. R., Krüger R. L., Bombardelli M. C. M., Machado C. S., Corazza M. L.(2018) Kinetics, composition and antioxidant activity of burdock (Arctium lappa) root extracts obtained with supercritical $\mathrm{CO}_{2}$ and co-solvent. Journal of Supercritical Fluids, 135, 25-33. doi: 10.1016/j.supflu.2017.12.034

Shi J., Yu J., Pohorly J., Young C., Bryan M., Wu Y. (2003) Optimization of the extraction of polyphenols from grape seed meal by aqueous ethanol solution. Journal of Food Agriculture and Environment, 1, 42-47.

Simić V. M., Rajković K. M., Stojičević S. S., Veličković D. T., Nikolić N. Č., Lazić M. L., Karabegović I. T. (2016) Optimization of microwave-assisted extraction of total polyphenolic compounds from chokeberries by response surface methodology and artificial neural network. Separation and Purification Technology, 160, 89-97. doi: 10.1016/j.seppur.2016.01.019

Singleton V. L., Orthofer R., Lamuela-Raventos R. M. (1999) Analysis of total phenols and other oxidation substrates and antioxidants by means of Folin-Ciocalteau reagent. Methods in Enzymology, 299, 152-178. doi:10.1016/S0076-6879(99)99017-1

Spigno G., Tramelli L., De Faveri D. M. (2007) Effects of extraction time, temperature and solvent on concentration and antioxidant activity of grape marc phenolics. Journal of Food Engineering, 81, 200-208. doi:10.1016/j.jfoodeng.2006.10.021

Sun Z., Su R., Qiao J., Zhao, Z. Wang, X. (2014) Flavonoids extraction from Taraxacum officinale (Dandelion): Optimisation using response surface methodology and antioxidant activity. Journal of Chemistry, 2014, 1-7. doi:10.1155/2014/956278 